\section{References}

1 Kannel WB, Castelli WP, Gordon T, McNamara PM. Serum cholesterol, lipoprotein and the risk of coronary heart disease. The Framingham study. Ann Intern Med $1971 ; 74: 1-12$.

${ }^{2}$ Epstein FH. Some uses of prospective observations in the Tecumseh community health study. Proc $R$ Soc Med 1967;60:56-60.

${ }^{3}$ Cochrane AL, Miall WE, Clarke WG. Results of a chest $\boldsymbol{x}$-ray survey in the Vale of Glamorgan: a study of an agricultural community. Tubercle 1956;37:417-25.

- Higgins ITT, Cochrane AL. Chronic respiratory disease in a random sample of men and women in the Rhondda Fach in 1958. Br f Ind Med 1961;18:93-102.

${ }^{5}$ Morris TG. A comparison of methods for the estimation of serum cholesterol and values in random samples of populations in the 55-64 age group. $\mathcal{f}$ Clin Pathol 1959;12:518-23.

- Baker RJ, Nelder JA. The GLIM system release 3 manual. Oxford: Numerical Algorithms Group, 1978.

7 Cox DR. Regression models and life tables. $\mathcal{F} R$ Stat Soc $B$ 1972;34: 187-220.

8 Committee of Principal Investigators. A co-operative trial in the primary prevention of ischaemic heart disease using clofibrate. $\mathrm{Br}$ Heart $\mathcal{f}$ 1978;40:1069-1118.

- Garrow JS. Weight penalties. Br Med $f$ 1979;ii:1171-2.

10 Truett J, Cornfield J, Kannel W. A multivariate analysis of the risk of coronary heart disease in Framingham. $\mathcal{F}$ Chronic Dis 1967;20:511-24.

(Accepted 10 March 1980)

\title{
Event recording in a clinical trial of a new medicine
}

\author{
R J SIMPSON， BRIAN TIPLADY，D C G SKEGG
}

\section{Summary and conclusions}

In a double-blind trial of the effect of zimelidine on weight and appetite 24 obese patients were allocated at random to receive either zimelidine or placebo for eight weeks followed by the alternative treatment for eight weeks. Possible adverse effects were elicited by asking patients at weekly intervals whether they had experienced any symptoms or ailments and recording all such "events" on a special form. A conventional checklist of symptoms was also used. Among 19 patients who completed the trial the two methods of recording yielded similar patterns of events. Of symptoms not on the checklist, insomnia was more common during treatment with zimelidine.

Event recording was found to be a practicable and convenient method of detecting possible adverse effects.

\section{Introduction}

The traditional method of detecting unwanted effects of drugs in clinical trials is to use checklists of predictable side effects or ask clinicians to report adverse reactions. In 1977 it was pointed out that unexpected side effects could be detected more reliably if doctors recorded all adverse events experienced by patients and not just those regarded as adverse reactions to drugs. ${ }^{1}$ The purpose of event recording would be not to replace clinical suspicion by "blind data-gathering" 2 but to supplement it. Although no one has advanced cogent arguments against using this procedure (which might also show unexpected benefits of drugs), it remains the exception rather than the rule in Britain. Since the practicability of the method has been questioned, we report here our experience of event recording in

\section{Health Centre, Bridge of Allan, Stirlingshire}

R J SIMPSON, MB, MRCPSYCH, general practitioner

Astra Clinical Research Unit, Edinburgh EH2 4NA

BRIAN TIPLADY, BA, PHD, clinical scientist

Department of Social and Community Medicine, University of Oxford, Oxford

D C G SKEGG, MB, DPHIL, lecturer (present appointment: professor of preventive and social medicine, University of Otago Medical School, Dunedin, New Zealand) a trial of the effect of a new bicyclic antidepressant, zimelidine, on body weight and appetite. This trial was carried out after preliminary studies in depressed patients had suggested that zimelidine might reduce appetite.

\section{Patients and methods}

The patients, who were not suffering from psychiatric illness, were adults attending a general-practice clinic for obesity. They consented to take part in a double-blind clinical trial. One week after an initial examination they were allocated at random to receive either zimelidine $100 \mathrm{mg}$ twice daily or matching placebo tablets. After eight weeks the treatments were reversed for a second period of eight weeks.

We report here only our assessment of possible adverse effects in patients who completed the trial; details of the weight changes and of patients who dropped out will be reported elsewhere. The patients were seen weekly and asked whether they had experienced any symptoms or ailments, including changes in chronic conditions. All such events were recorded on a special form, irrespective of whether a link with zimelidine was suspected. Every fourth week a conventional checklist of 21 symptoms was also used, but only after the patients had been asked to mention anything that had been bothering them.

The incidences of symptoms during the periods of treatment with zimelidine and placebo were compared by analysis of discordant pairs with McNemar's test. ${ }^{3}$

\section{Results}

Out of 24 patients who entered the trial, 19 (all women) completed the two eight-week periods; their mean age was 35 years.

The symptom checklist suggested that dry mouth and possibly constipation were associated with zimelidine treatment. The table gives the results of event recording, showing all symptoms mentioned by at least two women. An excess of insomnia occurred during treatment with zimelidine $(p<0.05)$. Six patients mentioned difficulty in sleeping only during the zimelidine period. Of these, four reported the symptom only during the first week of zimelidine treatment, and the others during the first two and three weeks respectively. Another woman reported insomnia during both treatment periods but mentioned it only once during the first period (placebo) and six times during the second (zimelidine). No other symptom was significantly more common during either period, although there was a tendency for dry mouth, constipation, and nausea to occur more often during treatment with zimelidine. The incidence of headache, which has been suspected as a side effect of zimelidine, ${ }^{4}$ was similar during the two periods.

Among 27 events mentioned by only one woman during either period were dysmenorrhoea, toothache, measles, sore eyes, and "feeling hungry." 
Events mentioned by at least two patients while taking zimelidine and placebo

\begin{tabular}{|c|c|c|c|c|c|c|}
\hline \multirow{2}{*}{\multicolumn{3}{|c|}{ Symptom or ailment }} & \multicolumn{2}{|c|}{ No of patients } & \multicolumn{2}{|c|}{ No of discordant pairs } \\
\hline & & & \multirow{2}{*}{ 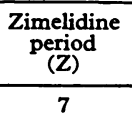 } & \multirow{2}{*}{$\begin{array}{c}\begin{array}{c}\text { Placebo } \\
\text { period } \\
(\mathrm{P})\end{array} \\
6\end{array}$} & \multirow{2}{*}{$\begin{array}{c}\begin{array}{c}\mathrm{Z} \text { positive, } \\
\text { P negative* }\end{array} \\
5\end{array}$} & \multirow{2}{*}{$\begin{array}{c}Z \text { negative } \\
\text { P positive } \\
4\end{array}$} \\
\hline $\begin{array}{l}\text { Headache } \\
\text { Tiredness or }\end{array}$ & .. & . & & & & \\
\hline sleepiness & $\ldots$ & .. & 7 & 5 & 3 & 1 \\
\hline Constipation & $\because$ & $\because$ & 7 & 4 & 4 & 1 \\
\hline $\begin{array}{l}\text { Dry mouth } \\
\text { Nausea ... }\end{array}$ & $\because$ & $\ddot{x}$ & $\begin{array}{l}8 \\
7\end{array}$ & $\begin{array}{l}2 \\
3\end{array}$ & $\begin{array}{l}7 \\
6\end{array}$ & $\frac{1}{2}$ \\
\hline Dizziness or & $\cdots$ & & & & & \\
\hline $\begin{array}{l}\text { fainting } \\
\text { Insomnia.. }\end{array}$ & $\because$ & $\because$ & $\begin{array}{l}5 \\
7\end{array}$ & 4 & 3 & 2 \\
\hline Depression & .. & $\therefore$ & 2 & $\frac{1}{5}$ & $\begin{array}{l}\mathbf{0} \\
0\end{array}$ & $3^{+}$ \\
\hline $\begin{array}{l}\text { Diarrhoea } \\
\text { Swelling of han }\end{array}$ & $\therefore$ ds and & $\because$ & 4 & 3 & 2 & 1 \\
\hline feet & .. & .. & 4 & 3 & 2 & 1 \\
\hline $\begin{array}{l}\text { Common cold } \\
\text { Itching or irrita }\end{array}$ & tion & . & 2 & 3 & $\overline{2}$ & 3 \\
\hline $\begin{array}{l}\text { of skin } \\
\text { Urinary frequen }\end{array}$ & con & .. & 3 & 2 & 3 & 2 \\
\hline (including no & cturia) & .. & 1 & 4 & 0 & 3 \\
\hline $\begin{array}{l}\text { Painful joints } \\
\text { Rash .. }\end{array}$ & 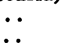 & $\because$ & $\frac{1}{2}$ & $\begin{array}{l}3 \\
2\end{array}$ & $\begin{array}{l}0 \\
1\end{array}$ & $\begin{array}{l}2 \\
1\end{array}$ \\
\hline $\begin{array}{l}\text { Agitation or } \\
\text { tenseness }\end{array}$ & $\ldots$ &. & 2 & 1 & 1 & 0 \\
\hline Dry skin .. & $\because$ & $\because$ & 2 & 1 & 2 & 1 \\
\hline Indigestion & $\because$ & $\because$ & 1 & 2 & 0 & 1 \\
\hline Influenza. . & $\therefore$ & . & 3 & 0 & 3 & 0 \\
\hline Tingling in han & & .. & 2 & 1 & 2 & 1 \\
\hline Vomiting.. & . & 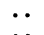 & 2 & 1 & 1 & 0 \\
\hline Backache & $\because$ & $\because$ & 1 & 1 & 1 & 1 \\
\hline Bad taste in mo & & $\because$ & 2 & 0 & 2 & 0 \\
\hline Excessive sweati & & $\ldots$ & 1 & 1 & $\overline{1}$ & 1 \\
\hline Trembling & .. & $\ldots$ & 2 & 0 & 2 & 0 \\
\hline
\end{tabular}

* Symptom occurred while patient taking zimelidine but not placebo. tSymptom occurred while patient taking placebo but not zimelidine. Significance of result: $p<0.05$.

\section{Discussion}

The nature and variety of symptoms recorded suggest that our method was successful in eliciting complaints other than those that patients or doctors might expect to be side effects of treatment. Thus, despite the small number of patients included in this trial, event recording yielded interesting findings.

Randomised controlled trials comparing the effects of zimelidine and amitriptyline in depressed patients have confirmed the prediction from animal experiments that zimelidine would produce fewer symptoms of anticholinergic activity than amitriptyline. ${ }^{56}$ The present study may indicate a weak anticholinergic effect of zimelidine, although the differences found were not statistically significant.

Because so many events were elicited in this study the excess of insomnia during treatment with zimelidine might be a chance finding. The main purpose of event recording, however, is to identify areas for further investigation, and it clearly did this. Insomnia was not included in our checklist of symptoms, so attention would not have been drawn to it as a possible adverse effect without the recording of events. Two objections that have been advanced against adopting event recording as a routine procedure are that the numbers of patients included in clinical trials are too small to yield useful results and that the method is too cumbersome. Our experience does not support these objections. While larger numbers would be more conclusive, analysing data from only 19 patients was clearly worth while. Moreover, the method was so convenient that it will probably be included in the expanded clinical trials that will be carried out when zimelidine is marketed.

Copies of the form used for recording events may be obtained from Dr Brian Tiplady.

\section{References}

1 Skegg DCG, Doll $\mathrm{R}$. The case for recording events in clinical trials. $\mathrm{Br}$ Med f 1977;ii:1523-4.

2 Weintraub M. Recording events in clinical trials. Br Med $\mathcal{f} 1978$;i :581.

3 Hills M, Armitage P. The two-period cross-over clinical trial, Br $\mathfrak{F}$ Clin Pharmacol 1979;8:7-20.

4 A berg A, Holmberg G. Preliminary clinical test of zimelidine (H102/09), a new 5-HT uptake inhibitor. Acta Psychiatr Scand 1979;59:45-58.

5 Coppen A, Rama Rao VA, Swade C, Wood K. Zimelidine: a therapeutic and pharmacokinetic study in depression. Psychopharmacology 1979 $63: 199-202$.

- Montgomery SA, McAuley R, Rani G, Montgomery DB. A double-blind comparison of the antidepressant efficacy of zimelidine, a new 5-HT uptake inhibitor, with amitriptyline. Abstracts of the 7th international congress of pharmacology (IUPHAR), Paris 1978. Oxford: Pergamon Press, 1978:246.

(Accepted 10 March 1980)

\section{SHORT REPORTS}

\section{Advice about driving after herniorrhaphy}

The increasing use of day care and short-stay surgery in the management of groin hernias has raised many questions. One common query by patients is "When may I drive ?" We have previously asked patients about the length of time before they drove and the answers ranged from four days to eight weeks. General practitioners give widely differing advice. ${ }^{1}$ We therefore carried out a study to try to answer the question "When may I drive?"

\section{Subjects, methods, and results}

The ability to perform an emergency stop in a car simulator before operation and on the third, seventh, and tenth postoperative days in 25 men who had right inguinal hernias was measured and compared with that of 20 normal subjects picked at random from the hospital staff. The car simulator consisted of a car seat and the usual three control pedals, above which were two lights, one green, one red. In addition a press button was held in the left hand. All were instructed to respond to the illumination of the green light by pressing the button and to the illumination of the red light by fully depressing the brake pedal as quickly as possible, as though performing an emergency stop. When the participant was seated comfortably he was asked to depress the accelerator pedal fully until one or other light came on and then respond appropriately. The delay between illumination of the light and the appropriate response was timed electronically. On each occasion the two responses were each tested 20 times in random order. Our intention was to measure and compare hand and foot reaction times and to see whether both were prolonged in the postoperative period or only the foot reaction time because of the presence of the groin incision.

The mean reaction time for each response on each test day was calculated. The hand reaction (button pressing) time was similar in both groups on each occasion (table). The foot (emergency stop) reaction time was also similar in the two groups preoperatively. On the third and seventh postoperative days the patients had significantly prolonged foot reaction times (paired $t$ test). The patients' foot reaction had returned to its preoperative time by the tenth postoperative day.

Mean $( \pm S D)$ hand and foot reaction times (seconds) in a group of patients before and after herniorrhaphy and a group of normal subjects

\begin{tabular}{cccccc}
\hline \multirow{2}{*}{$\begin{array}{c}\text { Preoperative } \\
\text { and } \\
\begin{array}{c}\text { postoperative } \\
\text { (days) }\end{array}\end{array}$} & \multicolumn{2}{c}{ Hand reaction time } & & \multicolumn{2}{c}{ Foot reaction time } \\
\cline { 2 - 3 } \cline { 5 - 6 } $\begin{array}{c}\text { Normal subjects } \\
(\mathrm{n}=20)\end{array}$ & $\begin{array}{c}\text { Patients } \\
(\mathrm{n}=25)\end{array}$ & & $\begin{array}{c}\text { Normal subjects } \\
(\mathrm{n}=20)\end{array}$ & $\begin{array}{c}\text { Patients } \\
(\mathrm{n}=25)\end{array}$ \\
\hline Preoperative & $\mathbf{0 . 5 1} \pm 0.1$ & $\mathbf{0 . 5 4} \pm 0.11$ & & $\mathbf{0 . 7 2} \pm 0.15$ & $\mathbf{0 . 7 1} \pm 0.12$ \\
Day 3 & $\mathbf{0 . 4 6} \pm 0.09$ & $\mathbf{0 . 5 1} \pm 0.11$ & & $\mathbf{0 . 7 0} \pm 0.10$ & $\mathbf{0 . 8 4} \pm 0.16^{*}$ \\
Day 7 & $\mathbf{0 . 4 6} \pm 0.09$ & $\mathbf{0 . 4 7} \pm 0.09$ & & $\mathbf{0 . 7 2} \pm 0.10$ & $\mathbf{0 . 7 7} \pm 0.14 \dagger$ \\
Day 10 & $\mathbf{0 . 4 9} \pm 0.13$ & $0.50 \pm 0.12$ & & $0.70 \pm 0.12$ & $\mathbf{0 . 7 1} \pm 0.15$ \\
\hline
\end{tabular}

